\title{
Agronomic descriptors and ornamental potential of passion fruit species ${ }^{(1)}$
}

\author{
DAIANE DA SILVA NÓBREGA ${ }^{(2)}$, JOSÉ RICARDO PEIXOTO(3), \\ MICHELLE SOUZA VILELA ${ }^{(3)}$, FÁBIO GELAPE FALEIRO(4), KAROLLINE DE PAULA SILVA GOMES(3), \\ ROSA MARIA DE DEUS DE SOUSA(3), ISADORA NOGUEIRA ${ }^{(3)}$
}

\begin{abstract}
Brazil has great variability, being one of the centers of origin of the genus Passiflora. Passion fruit has a multiple and diversified uses, being little explored as an ornamental plant in the country. The objective of this work was to characterize four passion fruit genotypes (two hybrid materials from the experimental field of passion fruit breeding program of the University of Brasília, and two passion fruit cultivars - BRS Sertão Forte and BRS Mel do Cerrado, both of them from Brazil), based on official and validated morphoagronomic descriptors for the identification of morphological aspects and ornamental potential, under field conditions, in the Distrito Federal, Brazil. The experiment consisted of a randomized block design, with four treatments, four replications, and six plants per plot. Plants were analyzed weekly regarding the characteristics of the branches, leaf blade, petiole, and flowers, with 24 measurements of each structure in the four treatments, which were recorded using a digital camera. Flowers presented pronounced size and color, colored branches, and leaves of varying sizes and shapes. All materials studied showed commercial ornamental potential to be explored as new options for ornamental climbing plants.
\end{abstract}

Keywords: Passiflora edulis, Passiflora alata, Passiflora cincinnata, climbing plant, ornamentation.

\section{RESUMO}

\section{Descritores agronômicos e potencial ornamental de espécies de maracujazeiro}

O Brasil é detentor de grande variabilidade, sendo um dos centros de origem do gênero Passiflora. O maracujazeiro tem uso múltiplo e diversificado, sendo pouco explorado como planta ornamental no país. O presente trabalho teve como objetivo a caracterização de quatro genótipos de maracujá (dois oriundos de cruzamentos de materiais do campo experimental de melhoramento genético de maracujazeiro da UnB e duas cultivares de maracujá - BRS Sertão Forte e BRS Mel do Cerrado) com base em descritores morfoagronômicos oficiais e validados para identificação de aspectos morfológicos e potencial ornamental, em condições de campo no Distrito Federal, Brasil. O ensaio foi instalado utilizando-se o delineamento experimental de blocos casualizados com quatro tratamentos, quatro repetições e seis plantas/parcela. As plantas foram analisadas semanalmente quanto às características dos ramos, limbo foliar, pecíolo e flores, sendo realizadas 24 mensurações de cada estrutura nos quatro tratamentos e feito registros fotográficos digitais. As plantas apresentaram flores de tamanho e cor pronunciados, ramos coloridos e folhas de formatos e tamanhos variáveis. Os dois cruzamentos e as cultivares estudadas possuem potencial ornamental comercial a ser explorado como novas opções de plantas trepadeiras ornamentais.

Palavras-chave: Passiflora edulis, Passiflora alata, Passiflora cincinnata, trepadeira, ornamentação.

\section{INTRODUCTION}

Passion fruit (Passiflora spp.) presents great genetic variability. The genus is composed of approximately 530 species, of which 150 to 200 are native to Brazil, with about 70 species that produce edible fruits (CARVALHO et al., 2017; FALEIRO et al., 2005). Brazil is one of the most important centers of passion flower diversity since most of wild Passiflora species occur in the center-north region of the country (FALEIRO et al., 2011).

The genus Passiflora presents a great morphological variability. It is composed of herbaceous or woody climbing plants and can occur in the form of herbs and shrubs of cylindrical or quadrangular, angular, suberified, glabrous or tomentose stems, and the main fruit species of Passiflora are morphologically differentiated based on their stems, number of petioles, petiole glands, bracts, seeds, and leaf and fruit (TEIXEIRA, 1994).

In the family Passifloraceae, both reproductive (especially flowers and bracts) and vegetative morphology (especially leaves and stipules) are too variable. For instance, foliar morphological differences represent the greatest variation described in angiosperms. In some cases, species can be distinguished only by the leaf morphology, such as Passiflora cirrhiflora Juss., from the Amazon region (FALEIRO et al., 2005).

\section{DOI: http://dx.doi.org/10.14295/oh.v23i3.1053}

(2) University of Brasília, Faculty of Agronomy and Veterinary Medicine, Brasília-DF, Brazil. *Corresponding author: daiane_nobrega@hotmail.com

(3) University of Brasília, Faculty of Agronomy and Veterinary Medicine, Brasília-DF, Brazil.

${ }^{(4)}$ Embrapa Cerrados, Brasília-DF, Brazil.

Licensed by CC BY 4.0 
Passion fruit is characterized by the multiple uses of its different parts, such as pulp, seeds, bark, flowers, leaves, and branches. These parts can be commercially explored in the form of natural consumption (sweet passion fruit), juices (passion fruit), flowers for ornamentation (ornamental passion fruit), and raw material for the food, condiment, cosmetic, and pharmaceutical industries (FALEIRO et al., 2015).

In Brazil, passion fruit is not widely used as an ornamental plant for commercial exploitation. However, passifloras are appreciated for their beautiful flowers resulting from a large variability of colors, sizes, and fragrances. Passiflorae flowers are considered as exotic and complex, some with a strong and bright color, others with a pale and soft color, mainly due to the presence of the crown, which characterizes the family Passifloraceae. In addition, the genus presents plants with diversified leaf shapes, and many species have ornamental value owing to this characteristic. Relevant aspects, such as the abundant number of flowers and the occurrence of flowering more than once a year, contribute to the use of passifloras in the ornamental plant market. However, further studies on floral phenology are necessary, such as in relation to the period, rate, peak, relative intensity, and mean duration of flowering, among others (MONTERO et al., 2013).

The objective of this study was to characterize four passion fruit genotypes based on morphoagronomic descriptors for the identification of morphological aspects and ornamental potential, under field conditions, in the Distrito Federal, Brazil.

\section{MATERIAL AND METHODS}

The study was conducted in the field from October 2016 to May 2017, at Água Limpa Experimental Farm, belonging to the University of Brasília (UnB), BrasíliaDF (lat. $16^{\circ} \mathrm{S}$; long. $48^{\circ} \mathrm{W}$; at $1,100 \mathrm{~m}$ asl). The climate of the region is considered as AW, according to the Köppen classification, with rainy summer (October-April) and dry winter (May-September) (KOTTEK et al., 2006). For the characterization of the meteorological conditions of the experimental period, climatological data were obtained from the daily database of the automatic meteorological station located at the experimental farm of University of Brasília, with records of $163.6 \mathrm{~mm}$ rainfall, $16.1^{\circ} \mathrm{C}$ average temperature, and $78.4 \%$ relative humidity (UNB, 2017).

The experiment consisted of a randomized block design with four treatments, four replications, six plants per plot, totaling 16 plots and 96 plants. Plants were conducted using a trellis fence system comprised of 6 m-distant wooden stakes and two pieces of smooth wire, at 1.60 and $2.20 \mathrm{~m}$ from the ground, with spacing of $3 \mathrm{~m}$ between rows and 2 $\mathrm{m}$ between plants. Passion fruit seedlings were sown and pre-rooted in polystyrene trays ( 72 cells), transplanted into polyethylene bags ( 2 liters), and finally planted in the field when they presented approximately $40 \mathrm{~cm}$ long.

Plants were watered by a drip irrigation system. Fertilization at planting ( $1 \mathrm{~kg}$ of super simple phosphate, $30 \mathrm{~g} /$ hole of FTE, $300 \mathrm{~g} /$ hole of limestone) and biweekly topdressing ( $30 \mathrm{~g} /$ plant of ammonium sulfate and $15 \mathrm{grams} /$ plant of potassium chloride) were carried out. Weeds were controlled by mechanical and manual hoeing in the rows and between rows, respectively.

Two hybrids of Passiflora edulis (MAR20\#24 x ECL7P1R4; MAR20\#21 x FB200P1R2) and two cultivars (BRS Sertão Forte (Passiflora cincinnata) and BRS Mel do Cerrado (Passiflora alata)) were evaluated. The hybrids were obtained from the passion fruit breeding program of the University of Brasília in partnership with Embrapa Cerrados.

Analyses were based on morphoagronomic descriptors, used in tests for distinguishability, homogeneity, and stability (DHS), obtained from official tables validated by the National Plant Variety Protection Service (SNPCMAPA) of Ministério da Agricultura, Pecuária e Abastecimento of Brazil (MAPA) and made available on their website (BRAZIL, 2016a; BRAZIL, 2016b).

Plants were weekly analyzed for the characteristics of branches, leaf blade, petiole, and flowers, with 24 measurements of each structure in the four treatments, recorded using a digital camera. Branches were young and vigorous, resulting from spring budding, not fully lignified; leaves were fully developed from the middle third of the branch, during the growing season. Flowers were at full anthesis, with no damage (from pest attack or weather actions) (JESUS et al., 2015; JESUS et al., 2016).

The following characteristics were observed in the hybrids and cultivars: branches - predominant color; leaf blade - length, maximum width, predominant sinus depth, texture; petiole - nectaries length and predominant position; flowers - diameter of petals and sepals), diameter of the crown (fimbriae), shape of the longest crown filaments, presence or absence of colored rings in the crown filaments, width of the colored rings in the crown filaments, length of the androgynophore, presence or absence of anthocyanin in the androgynophore, presence or absence of anthocyanin in the filaments, presence or absence of anthocyanin in the stylet (BRAZIL, 2016a).

In addition, the following characteristics were observed in the two hybrids: flowers - length of the bract, length of the sepal, width of the sepal; and in the two cultivars: branches - predominant shape, predominant division, hairiness; flowers - predominant color of the crown, number of colored rings in the crown filaments, and shape of the hypanthium (BRAZIL, 2016b).

\section{RESULTS AND DISCUSSION}

Cultivar BRS Sertão Forte ( $P$. cincinnata) presented flowering at three months after planting with predominant anthesis in the morning. Plants remained at flowering stage during the seven months of observation, with the greatest number of flowers in the rainy season. Flowers remained open during the day, with a mean diameter of $>$ 6 to $9 \mathrm{~cm}$; petals, sepals, and crown were predominantly purple; the diameter of the crown was large, ranging from 9 to 12 centimeters, with long, wavy filaments, and more than one colored ring. The androgynophore was very long 
( $>3 \mathrm{~cm}$ ); the presence of anthocyanin was strong in the androgynophore, filament and stylet. Moreover, flowers presented mean length for bracts ranging from 2 to $4 \mathrm{~cm}$; mean length of petals varying from 1 to $2 \mathrm{~cm}$; and mean length and width of sepals ranging from 3 to $6 \mathrm{~cm}$ and 1 to $2 \mathrm{~cm}$, respectively. The hypanthium presented campanulate shape. The leaf blade showed mean length between $>8$ and $12 \mathrm{~cm}$ and mean width between $>12$ and $16 \mathrm{~cm}$; it was sectioned with deep sinus, pentalobed, bullate, with absence of hairs. The petiole showed a mean length of 2-4 $\mathrm{cm}$, with nectaries adjacent to the branch. Branches were purple (Figure 1).

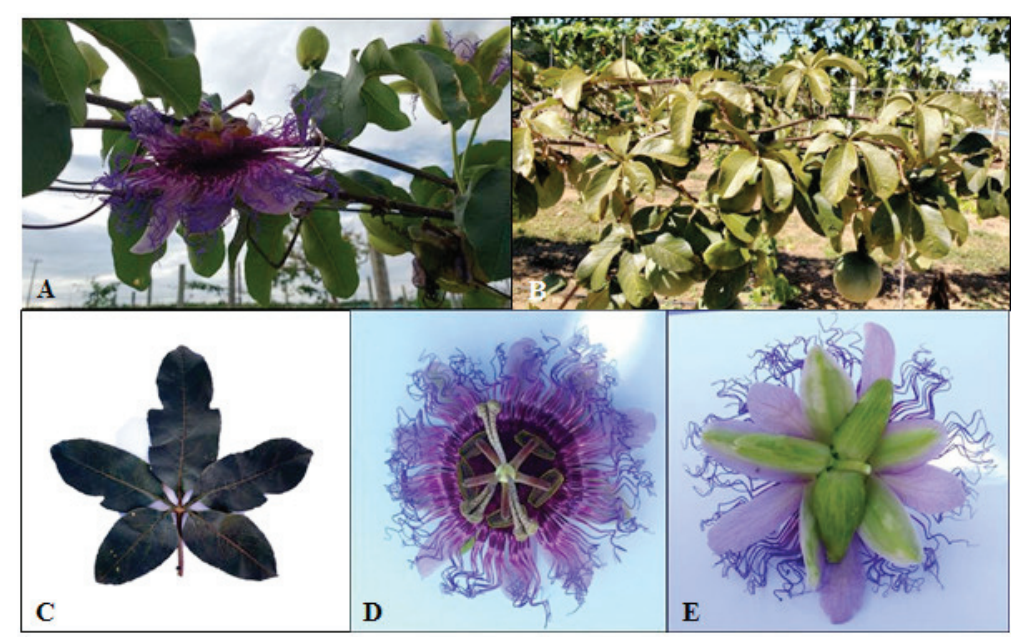

Figure 1. Sertão Forte Cultivar (Passiflora cincinnata). A and B. Purple Branches. C. Pentalobed leaf with deep sinus, bullate, with absence of hairs, and with nectaries adjacent to the branch. D and E. Flowers with mean diameter of $>6-9 \mathrm{~cm}$, with predominantly purple petals, sepals and crowns. Authorship: Daiane da Silva Nóbrega, 2017.

Silva et al. (2015) claim that $P$. cincinnata is a wild passion fruit species with potential for ornamentation due to the color of its flowers. In somatic embryogenesis, the species is considered as a model plant of the Passiflora genus, enabling the production of synthetic seeds. Protocols for dormancy overcome of some passion fruit species (Passiflora quadrangularis, $P$. nitida, $P$. foetida, $P$. eichleriana, P. alata, $P$. cincinnata, $P$. mucronata, $P$. micropetala, $P$. suberosa, $P$. morifolia and $P$. tenuifila) have been tested and demonstrated positive results, allowing the establishment of commercial production of species with high ornamental potential (MOROSTEGA et al., 2017).

The genus Passiflora comprises herbaceous and woody climbing plants, whose ornamental value is conferred by the beautiful flowers, owing to their size, color and shape. These characteristics allow the ornamental use of several species as a landscape solution for large and medium areas, potting, pergola shading hedges, and for the replacement of ornamental climbing plants commonly used to cover walls and arbor (FALEIRO et al., 2005).

Pyrostegia venusta (Ker Gawl.) Miers is a plant of the family Bignoniaceae, native to the Brazilian Cerrado, popularly known as "cipó-de-são-joão" (MOSTAFA, 2013). This species has physiological characteristics distinct from those of Passiflora, but it is a morphologically similar climbing plant, presenting tendrils, woody branches, trifoliate leaves, and with capacity of shading, being commonly used in ornamentation. In this way, ornamental passion fruit species can be an alternative to $P$. venusta.

Pyrostegia venusta (Ker Gawl.) Miers is a woody climbing plant, with multiple tendrils (the ends are branched again, bifid or trifid). Its branches are 6-8-angular, glabrous to villous, and striated. Its leaves are 2-3 foliolate, opposite; the leaf blade measures $4.5-6.5 \times 2.3-3.5 \mathrm{~cm}$, and is oval to oblong-lanceolate, glabrous to puberulous. Inflorescences occur in the form of panicles with corymbos; the calyx is campanulate, subtruncate, with $0.5 \mathrm{~cm}$ in length. The crown presents orange to yellow coloration, valvar prefloration, glabrous externally, with linear-elongated, flattened capsules of $25-30 \mathrm{~cm}$ in length (VILLAGRA and ROMANIUC NETO, 2011).

Cultivar BRS Mel do Cerrado (P. alata) flowered at 90 days after planting, with predominant anthesis in the morning. Plants presented continuous and diurnal flowering during the observation period, with flowering peak in the rainy season. The mean diameter of the flower $(>6-9 \mathrm{~cm})$ and crown $(>6-9 \mathrm{~cm})$ result in the ornamental beauty of the flowers. In addition, the sepals and petals are purplish red, and the crown is purplish blue. The crown presented long wavy filaments, with more than one colored ring. No anthocyanin was observed in the reproductive structures (androgynophore, filament, and stylet). The androgynophore had a short length $(0.5-1 \mathrm{~cm})$. Flowers presented short bracts $(<2 \mathrm{~cm})$; the sepals had mean length of 3 to $6 \mathrm{~cm}$, and mean width of $1-2 \mathrm{~cm}$; the petals presented mean length of 3-6 cm. The hypanthium of the flowers was campanulate. The leaf blade did not present sinus nor pilosity; it is predominantly cordate and bullate, with $>12-16 \mathrm{~cm}$ in length, and mean maximum width of $>4-12 \mathrm{~cm}$. The petiole was long $(>4 \mathrm{~cm})$, and nectaries were distributed along the petiole. Plants showed purple green branches (Figure 2). 


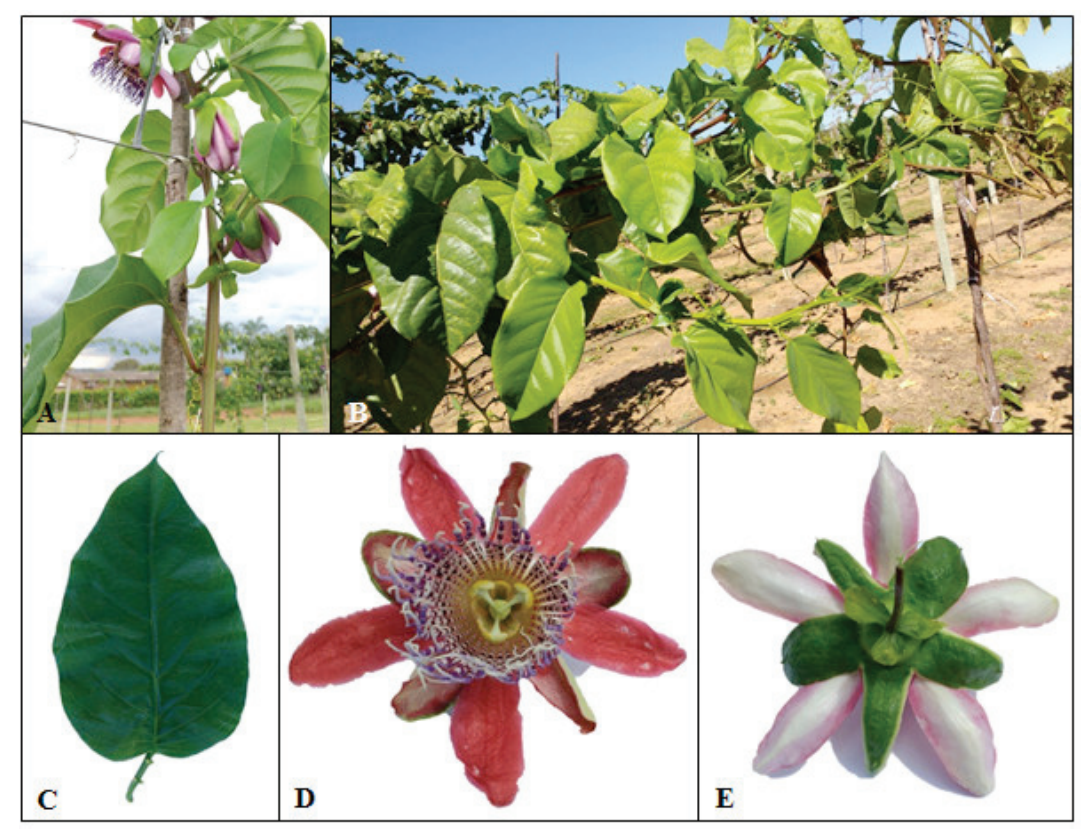

Figure 2. Mel do Cerrado (Passiflora alata) cultivar. A and B. Purplish green branches. C. Cordate leaf, bullate, without pilosity; nectaries distributed along the petiole. D and E. Flowers with mean diameter of $>6-9 \mathrm{~cm}$,

with purplish red sepals and petals, and purplish blue crown. Authorship: Daiane da Silva Nóbrega, 2017.

The genotypes originated from the crosses between MAR20\#24 x ECL7P1R4 and MAR20\#21 x FB200P1R2 (UnB) presented several common characteristics. The anthesis of the flowers was continuous and predominant in the afternoon, with flowering peak in the rainy season. Flowers are white, with a large diameter $(>7-9 \mathrm{~cm})$ and large crown $(>7-9 \mathrm{~cm})$, colored rings, dark purple crown filaments $(>1.5 \mathrm{~cm})$, wavy at the end. The flowers have filaments slightly pigmented with anthocyanin, short androgynophore $(0.5-1 \mathrm{~cm})$, and sepals with mean length of
$3.5-4 \mathrm{~cm}$ and mean width of $<1.5 \mathrm{~cm}$. Both genotypes show purplish green branches and leaf blade with deep sinus, bullate, mean petiole of $>3-4 \mathrm{~cm}$, and nectaries adjacent to the leaf blade. However, the two hybrids differed in relation to the characteristics of leaf blade length and width, bract length, and amount of anthocyanin in the androgynophore and stylet. The genotype MAR20\#24 x ECL7P1R4 showed mean leaf blade of $>12-15 \mathrm{~cm}$ and mean width of $>15-18$ $\mathrm{cm}$, long bracts $(>3 \mathrm{~cm})$, and androgynophore and stylet with intermediate anthocyanin pigmentation (Figure 3 ).

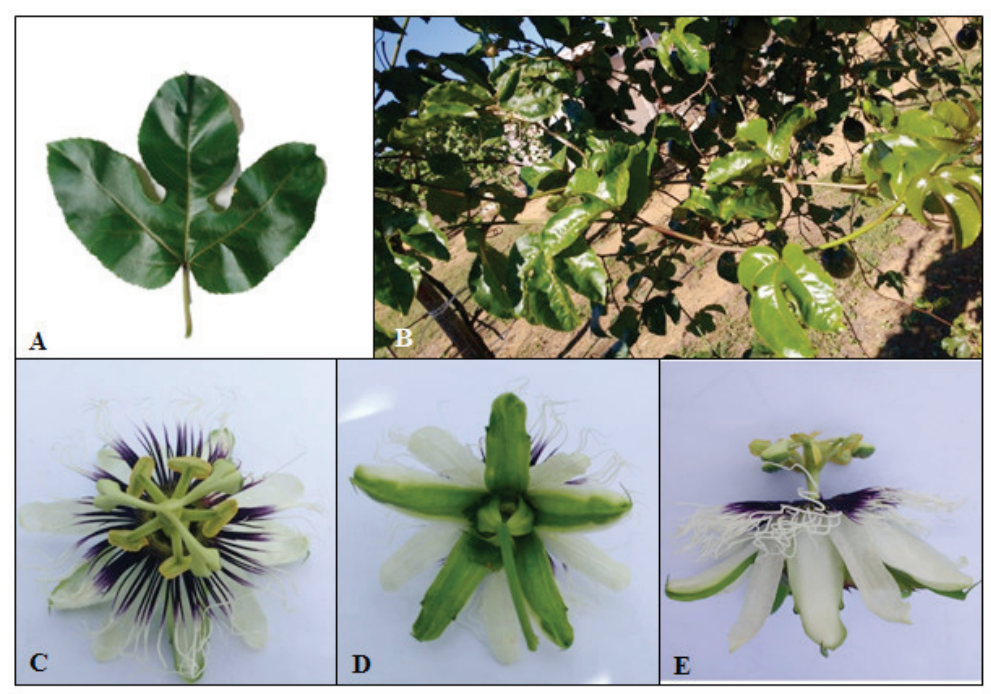

Figure 3. Cross MAR20 \# 24 x ECL7 P1 R4 (Passiflora edulis Sims). A. Leaf with deep sinus and bullate, petiole with nectaries adjacent to the leaf blade. B. Purplish green branches. C, D, and E. White flowers with diameter of $>7-9 \mathrm{~cm}$, and dark purple crown. Authorship Daiane da Silva Nóbrega, 2017.

The genotype MAR20\#21 x FB200P1R2 presented short $(<8 \mathrm{~cm})$ and very wide $(>18 \mathrm{~cm})$ leaf blade; bracts with mean length of 2-3 cm), and no or slight anthocyanin pigmentation in the androgynophore and stylet (Figure 4). 


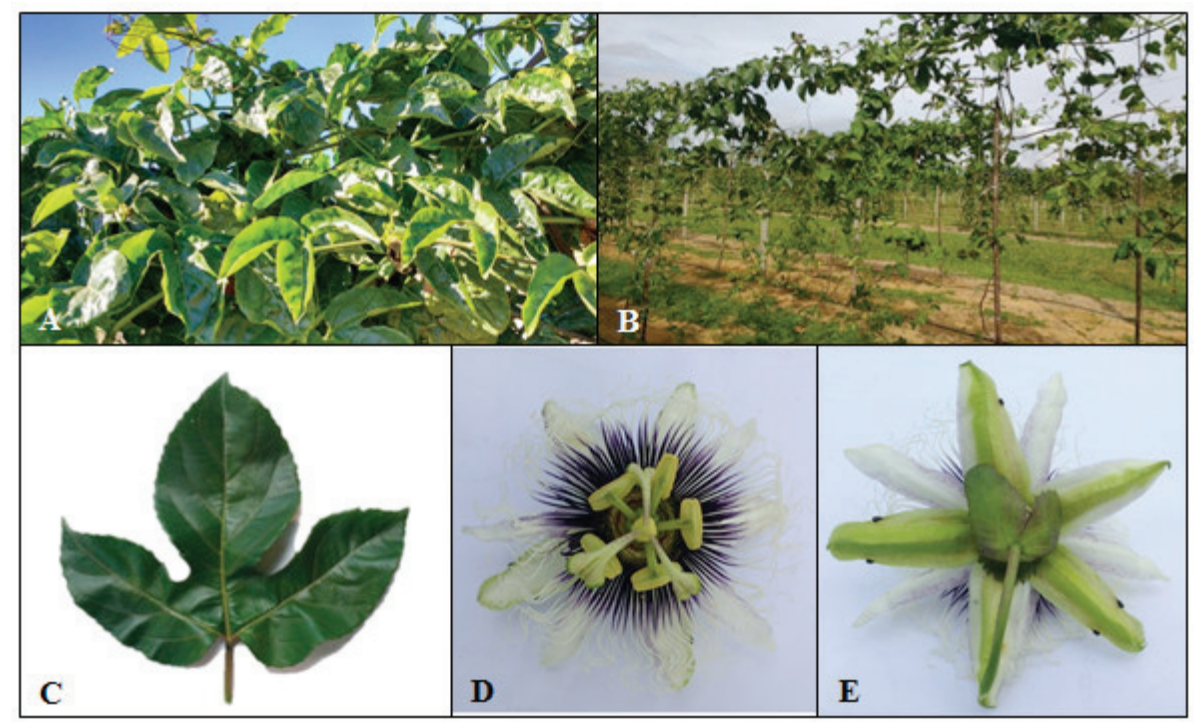

Figure 4. Cross MAR20 \# 21 P2 x FB200 P1 R2 (Passiflora edulis Sims). A and B.

Purplish green branches. C. Leaf with deep sinus and bullate, petiole with nectaries adjacent to the leaf blade. D and E. White flowers with diameter of > 7-9 cm, and dark purple crown. Authorship Daiane da Silva Nóbrega, 2017.

Other Passiflora species have also been reported as a new alternative for ornamental cultivation. $P$. quadrangularis presents multiple, simultaneous purple and white flowers in anthesis; moreover, flowers are large, fragrant, with long flowering during the year. The species has edible fruits, exuberant and medicinal leaves that provide shading for outdoor recreational areas and/or other cultivated plants (MONTERO et al., 2013). P. mucronata has white, phosphorescent flowers and nocturnal anthesis, which attracts moths and bats. The plant is cold-tolerant, with intermediate vegetative vigor; intense flowering, which extends over a long period of the year (MELETTI et al., 2011). These characteristics amplify the value of these species and make them particularly interesting for use in arbor and hedges. However, the effective use of Passiflora in the market of ornamental plants depends on studies on floral phenology.

Several passion fruit species, known as "wild or native", are being studied, i.e., they have not yet been manipulated by humans, and many of them present ornamental potential. These species are at the initial stage of genetic and cultural breeding, i.e., they are under a domestication process to be used as ornamental plants for commercialization. Agronomic evaluations of Passiflora wild germplasm have shown potential to be used in the supply of genes of interest for genetic breeding, including some accessions of $P$. setacea, $P$. mucronata, P. alata. P. cincinnata, and $P$. quadrangular (FALEIRO et al., 2015).

\section{CONCLUSIONS}

The two hybrids (Passiflora edulis) and the two cultivars (Passiflora alata and Passiflora cincinnata) evaluated in this study have commercial ornamental potential to be explored, under field conditions, in the Distrito Federal, Brazil. Thus, they may become new options for ornamental climbing plants to be used in parks, gardens, residences, etc., presenting different shading intensities.

\section{ACKNOWLEDGMENTS}

The authors are thankful to the Coordination for the Improvement of Higher Education Personnel (Capes) for the scholarship granted to the first author. Also, to the University of Brasília (UnB), for the infrastructure and technical support. And to Embrapa Cerrados, for the supply of passion fruit genetic material.

\section{AUTHORS CONTRIBUTIONS}

DSN: Field analysis, data collection, data analysis and interpretation, paper preparation, critical review of the article. JRP: Data analysis and interpretation, critical review of the paper, final approval of the version to be published. MSV: Data analysis and interpretation, critical review of the paper, final approval of the version to be published. RMDS: Data analysis and interpretation, critical review of the paper, final approval of the version to be published. FGF: Granting of seedlings of wild passion fruit species. KPSG: Field analysis, data collection, and final approval of the version to be published. IN: Field analysis, data collection, critical review of the paper, final approval of the version to be published.

\section{REFERENCES}

BRAZIL. Ministry of Agriculture, Livestock and Supply. Protection of cultivars. Instructions for carrying out the trials of distinguishing, homogeneity and stability of passion fruit cultivars (Passiflora edulis Sims). Available at: $(<\mathrm{http}: / /$ www.agricultura.gov.br/assuntos/insumos-agropecuarios/ insumos-agricolas/protecao-de-cultivar/frutiferas $>$ ). Accessed on: September 09, 2106a. 
BRAZIL. Ministry of Agriculture, Livestock and Supply. Protection of cultivars. Instructions for carrying out the trials of distinguishing, homogeneity and stability of passion fruit cultivars (Passiflora L. and interspecific hybrids) except Passiflora edulis Sims. Available at: (<http://www.agricultura.gov.br/assuntos/insumosagropecuarios/insumos-agricolas/protecao-de-cultivar/ frutiferas $>$ ). Accessed on: September 09, 2106b.

CARVALHO, P.P.; ANTONIAZZI, C.A.; SILVA, N.T.; MIKOSVKI, A.I.; CARVALHO, I. F.; CARVALHO, M.L.S. Regeneração in vitro de Passiflora miniata Mast. Ornamental Horticulture, v.23, n.1, p.88-95, 2017. DOI: http://dx.doi.org/10.14295/oh.v23i1.965

FALEIRO, F.G.; JUNQUEIRA, N.T.V.; BRAGA, M.F. Germplasm and genetic improvement of passion fruit research challenges. In: FALEIRO, F.G.; JUNQUEIRA, N.T.V.; BRAGA M.F. (Ed.). Passion fruit: germplasm and genetic improvement. Planaltina: Embrapa Cerrados, 2005. p.187-210.

FALEIRO, F.G.; JUNQUEIRA, N.T.V.; BRAGA, M.F.; OLIVEIRA, E.J.; PEIXOTO, J.R.; COSTA, A.M. Germoplasma e Melhoramento Genético do Maracujazeiro - histórico e perspectivas. Planaltina: Embrapa Cerrados, 2011.36p.

FALEIRO, F.G.; JUNQUEIRA, N.T.V.; COSTA, A.M. Research and development actions for the diversified use of commercial and wild passion fruit species (Passiflora spp.). Planaltina: Embrapa Cerrados, 2015. 26p.

JESUS, O.N.; OLIVEIRA, E.J.; FALEIRO, F.; SOARES, T.L.; GIRARDI, E.A. Illustrated morphoagronomic descriptors Passiflora spp. Brasília: Embrapa, 2016. 122p.

JESUS, O.N.; OLIVEIRA, E.J.; SOARES, T.L.; FALEIRO, F.G. Application of morphoagronomal descriptors used in DHS test of passion fruit cultivars (Passiflora edulis Sims): practical manual. Brasília: Embrapa, 2015. 33p.

KOTTEK, M.; GRIESER, J.; BECK, C.; RUDOLF, B.; RUBEL, F. World map of the Köppen-Geiger climate classification updated. Meteorologische Zeitschrift, v.15, n.3, p.259-263, 2006.
MAROSTEGA, T.N.; LUZ, P.B.; TAVARES, A.R.; NEVES, L.G.; SOBRINHO, S.P. Methods of breaking seed dormancy for ornamental passion fruit species. Ornamental Horticulture, v.23, n.1, p.72-78, 2017. DOI: $<$ http://dx.doi.org/10.14295/oh.v23i1.982>

MELETTI, L.M.M.; SOARES-SCOTT, M.D.; BERNACCI, L.C.; ALVARES, V.; AZEVEDO FILHO, J.A.de. Characterization of Passiflora mucronata Lam.: new alternative of ornamental passion fruit. Ornamental Horticulture, v.17, n.1, p.87-95, 2011.

MONTERO, D.A.V.; MELETTI, L.M.M.; MARQUES, M.O.M. Flowering phenology and perfume characteristics of Passiflora quadrangularis 1. (Melon-passion fruit). Ornamental Horticulture, v.19, n.2, p.99-106, 2013.

MOSTAFA, N.M.; EL-DAHSHAN, O.; SINGAB, A.N.B. Pyrostegia venusta (Ker Gawl.) Miers: a botanical, pharmacological and phytochemical review. Medicinal Aromatic Plants, v.2, n.3, p.123, 2013.

SILVA M.L.; PINTO, D.L.P.; GUERRA, M.P.; LANII, E.R.G.; CARVALHO, I.F.; ROSSI, A.A.B.; OTONI, W.C. Production of synthetic seeds of wild passion fruit with ornamental potential. Ornamental Horticulture, v.21, n.3, p.331-338, 2015.

TEIXEIRA, C.G. Maracujá. In: ITAL, Cultura, Matériaprima, processamento e aspectos econômico. Campinas: ITAL, 1994. p.1-142.

UnB. Automatic Weather Station Database (Daily Data). Fazenda Água Limpa/University of Brasília - FAL/ UnB. Available at: <http://www.fav.unb.br/86-facultyveterinaria/128-base-de-dados-estacao-automatica-dadosdiarios $>$ Accessed in: August, 2017.

VILLAGRA, B.L.P.; ROMANIUC NETO, S. Climbing plants of the State Park of the Fontes do Ipiranga (São Paulo, Brazil). Hoehnea, v.38, n.3, p.325-384, 2011. 